FILOZOFIA

Roč. 75, 2020, č. 2

DOI: https://doi.org/10.31577/filozofia.2020.75.2.4

\title{
K PROBLEMATIKE GEOMETRIZOVANIA KRÁSY A ESTETICKÝCH POJMOV
}

ANDREJ DÉMUTH, Právnická fakulta, Univerzita Komenského v Bratislave, Bratislava, SR

DÉMUTH, A.: On the Problematics of Geometrizing Beauty and Aesthetic Terms FILOZOFIA, 75, 2020, No 2, pp. $121-132$

The following text presents a philosophical and linguistic attempt to propose a cognitive-semantic tool allowing for a more precise definition and clarification of the meanings and structures of the terms beauty and aesthetic experience. The presented analysis stems from Gärdenfors's theory of conceptual spaces and the premise that beauty and aesthetic experience create multidimensional conceptual spaces. The conceptual analysis of the basic terms, related concepts and connected dimensions will be used in their exploration, both in the everyday language, as well as in the specialized-scientific understanding (philosophy, aesthetics). The text also presents the results of the empirical research carried out by George Hosoya on mapping the terms of aesthetic emotions, which are put in context with the Gärdenfors's model. It attempts to analyze our understanding of the basic moments and structures of aesthetic experience, as well as the possibilities in the research in them, by uncovering and describing different dimensions of the experience of beauty.

Keywords: Beauty - Aesthetic experience - Semantic space - Conceptual analysis

Problém krásy patrí k najkomplikovanejším otázkam filozofického, estetického a umenovedného bádania. Dôvod, prečo je to tak, tkvie v nejasnosti samého pojmu krása, ako aj v tom, čo tento pojem označuje. Napriek úsiliu filozofov dodnes nemáme žiadnu definíciu krásy, ktorá by u filozofov vyvolávala spokojnost’ a všeobecný súhlas. ${ }^{1}$ Akoby dokonca panoval názor, že krása je už zo svojej podstaty nedefinovatel'ná, že existuje nekonečne vel’a druhov krás (Levinson 2004) a diametrálne odlišných prvkov, aspektov či komponentov, ktoré nám neumožňujú jej úplné vystihnutie, ba dokonca ani dostatočné porozumenie tomuto problému. ${ }^{2}$

V rôznych jazykoch vychádzame pri označovaní krásy z celkom odlišných termínov a etymologických základov. Práve terminologická rozmanitost’ pojmu krása

\footnotetext{
${ }^{1}$ Ako ukazuje U. Eco (2005), každé historické obdobie si vypracovalo vlastné chápanie a ideál krásy a je vel'mi otázne, či možno tieto predstavy previest' na nejaký spoločný nadčasový a kultúrne nepodmienený menovatel'.

${ }^{2} \mathrm{O}$ odlišnostiach vo fenomenologickom prístupe ku kráse pozri napr. Démuth (2019b) a v evolucionistickom napr. Démuthová (2019).
} 
(a to v mnohých - aj vel'mi príbuzných jazykoch) naznačuje, že pri jej označovaní sa často zameriavame na celkom odlišné aspekty tohto mnohoúrovňového a multidimenzionálneho pojmu. V tom, že sme zameraní na odlišné dimenzie a aspekty daného pojmu, pravdepodobne tkvie aj nejasnost' a konfúznost' nášho uvažovania o kráse. Pri estetických súdoch často dospievame $\mathrm{k}$ nesúhlasu, ktorý býva neraz pripisovaný subjektivizmu, relativizácii či nejasnosti pojmov. A práve o jej odstránenie nám vo filozofii ide. Vážnym lingvisticko-filozofickým problémom však je, či možno vôbec vytvorit' jednotný koncept krásy, ktorý by zmapoval všetky (či aspoň tie podstatné) jej dimenzie, a objasnit' ním niektoré ich vzájomné vzt’ahy. Je takýto koncept množný? Bol by univerzálny, alebo kulturálne a lingvisticky determinovaný? Aký je vztah krásy a estetickej skúsenosti, pôžitku a estetickej hodnoty či subjektivity a objektivity v estetickom skúmaní?

\section{Dva pokusy ako mapovat' sémantické priestory estetických pojmov}

\section{1/ Gärdenforsovo geometrizovanie významu}

$S$ teóriou mapovania sémantických priestorov niektorých pojmov prirodzeného jazyka prišiel filozof a kognitívny vedec Peter Björn Gärdenfors (2000; 2013; 2014; 2015), ktorý predstavil projekt mapovania významov niektorých pojmov prostredníctvom ich geometrického znázorňovania. Konceptuálny priestor je podl'a neho geometrická štruktúra, ktorá predstavuje množstvo kvalitatívnych rozmerov označujúcich základné vlastnosti, ktorými porovnávame pojmy a objekty, ako sú hmotnost', farba, chut', teplota, rozostup a tri klasické priestorové dimenzie. Príkladom takéhoto konceptu je pojem farba, ktorej základné dimenzie sú odtieň, jas a sýtost’ a každý bod jej konceptuálneho priestoru ${ }^{3}$ reprezentuje konkrétnu farbu s konkrétnym jasom a odtieňom. Jednotlivé konvexné regióny tohto priestoru potom predstavujú konkrétne pojmy, ktorými danú farbu označujeme (červená, žltá, modrá). Dôležitou súčast'ou Gärdenforsovej teórie je presvedčenie, že prirodzené kategórie sú konvexnými oblast'ami konceptuálnych priestorov, ${ }^{4}$ ktoré umožňujú identifikovat' a interpretovat' ohniskové body ako kategoriálne prototypy. V prípade farby pojem (napríklad okrovej farby) vytvára konvexný sémantický región, ktorý obsahuje všetky možné objekty a ich pomenovania, ktoré patria pod tento pojem skôr ako pod akýkol'vek iný. To značí, že vo všeobecnom pojme farba vieme identifikovat' a lokalizovat' konkrétne rovinné či priestorové subregióny, ktoré označujú konkrétne druhy farby, a mapovat' vzt'ahy medzi nimi, ale aj „logiku“ celého pomenovania. A hoci Gärdenforsov teoretický

\footnotetext{
${ }^{3}$ Konceptuálny priestor pojmu farba možno znázornit' gul'ou s centricky uloženým priesečníkom troch osí (jas, odtieň, sýtost'), alebo klasickým Munsellovým vretenom.

${ }^{4}$ To znamená, že ak nejaké dva prvky patria do nejakého regiónu a tretí sa nachádza niekde medzi nimi, tak aj tento tretí prvok bude patrit' do daného regiónu.
} 
koncept nie je všeobecne prijímaný na všetky rozmanité oblasti sémantiky jazyka (Zenker, Gärdenfors 2015), jeho model (aj vd’aka jeho možnému algoritmizovaniu) môže byt' úspešne uplatňovaný na objasnenie významových obsahov vybraných pojmov v prirodzenom jazyku.

Na základe uvedenej teórie a predpokladu, že pojmy krása a estetická skúsenost' predstavujú multidimenzionálne sémantické priestory, som načrtol geometrický model sémantického priestoru pojmu krása (Démuth 2017). Prostredníctvom geometrie sémantických priestorov jednotlivých estetických pojmov by tak mohlo byt' možné vymedzit' jednotlivé regióny, ktoré tieto pojmy v sémantickom priestore zastávajú, ale aj ich základné vzt’ahy, a načrtnút či mapovat' obsahy jednotlivých sémantických priestorov pojmov. Empirickým výskumom - zberom a základným spracovaním najčastejších konotátov pojmu krása v slovenskom jazyku, ako aj konceptuálnou analýzou vybraných príbuzných pocitov a na ne poukazujúcich odvodených pojmov (akými sú atraktivita, páčenie sa, vznešeno) - možno identifikovat' základné dimenzie pojmu krása (subjektivita-objektivita, príjemno-nepríjemno, dokonalost'-nedokonalost', výnimočnost'-každodennost', jednoduchost'-komplexita, aktivita-pasivita) ako predpokladaného kl'účového subregiónu všeobecnejšieho pojmu estetická skúsenost'. Klúčovou charakteristikou daného modelu bolo chápanie uvedených dimenzií ako bipolárnych kontinuí, ktorých kombinácie (ako odlišné osi geometrického priestoru) vymedzujú sémantický priestor pojmu krása a umožňujú ho geometricky opísat'.

\section{2/ Hosoyovo mapovanie pojmov estetických emócií}

Približne v tom istom čase publikoval George Hosoya a kol. (2017) štúdiu, ktorej predmetom bolo mapovanie základných pojmov estetických skúseností v nemeckom, resp. v anglickom jazyku. Ide o štúdiu Inštitútu Maxa Plancka pre empirickú estetiku, ktorý nadväzuje na filozofické tradície fechnerovskej estetiky budovanej „zdola“ v spojení s aktuálnymi výskumami v oblasti psychológie, lingvistiky, neurovied a teórie umenia. Ich hlavným zámerom bolo vybudovat' a ozrejmit' koncept „estetických emócií “5, ktorý v súčasnosti nie je filozofmi či estetikmi jednoznačne prijímaný. Napriek tomu i napriek odlišnej metodológii ich výskumu voči Gärdenforsovmu

\footnotetext{
${ }^{5}$ Menninghaus a kol. (2019b) definujú estetické emócie ako diskrétne emočné stavy, ktoré napriek všetkým ich odlišnostiam 1) vždy zahŕňajú estetické hodnotenie objektu, 2) sú charakteristické istou estetickou naladenost'ou, 3) sú spojené so subjektívnym pocitom potešenia alebo nespokojnosti, 4) sú dôležitým prediktorom výsledného páčenia sa alebo nepáčenia, 5) hodnotia rôzne typy vnímaných estetických prít’ažlivostí, 6) kategoricky sa líšia od ostatných tried emócií,...
} 
teoretickému modelu, ${ }^{6}$ sa nazdávam, že ich empirický výskum môže byt' osožný pre testovanie použitel'nosti predloženého sémantického konceptu.

Uvedená Hosoyova lingvisticko-estetická analýza na základe zberu a spracovania empirických dát (na vzorke 60 študentov umeleckých a umenovedných predmetov Freie Universität Berlin) dospela k záveru, že estetické emócie, ktoré jej autori vnímajú ako osobitý typ emocionálnych stavov, ${ }^{7}$ ktoré obsahujú vždy aj estetické hodnotenie, možno rozdelit' na tri základné druhy, a to podl'a charakteristík ich prežívania. Prvú skupinu mapovaných emócií predstavovali negatívne pocity a negatívne hodnotenie. Druhý klaster estetických pocitov prezentovali najmä emocionálne pozitívne pocity, nálady a rozpoloženia, založené na pocitovaní príjemnosti, páčenia sa a pôžitku. Esteticky najzaujímavejšími sa však zdajú byt' emócie uznania, zaujatia, intelektuálnej aktivity a motivačné stavy, ktoré nie sú čisto príjemné, ale môžu byt' vo väčšej miere zmiešanej povahy (Menninghaus et al. 2017). Ich analýza ukázala, že ambivalentné a nejednoznačné emócie sú esteticky pre vnímanie jedinca najvýznamnejšie a práve tieto emócie predstavujú prototyp estetických emócií pretože sú najkomplexnejšie a často sprevádzajú aj najintenzívnejšie estetické skúsenosti.

Z kantovského ponímania estetického súdu ako produktu reflektujúcej súdnosti vieme, že hodnotenie je základným prvkom estetickej skúsenosti. Kant $(1975,51)$ ukázal, že hodnotenie je vždy späté s pocit’ovaním príjemných alebo nepríjemných emocionálnych stavov - s pocitom, že sa nám niečo páči, alebo, naopak, s odporom. Estetický súd je teda založený na reflexii a hodnotení vlastných pocitov. Na druhej strane však estetické páčenie, ktoré určuje súd vkusu, má byt' podl'a Kanta nezaujaté, celkom bez záujmu. $\mathrm{V}$ opačnom prípade by si súd nemohol nárokovat' na všeobecnú platnost' a záväznost'. Avšak zál'uba v príjemnom je vždy spojená so záujmom. Ako teda tento paradox vyriešit? Jednoducho - podl'a Kanta veci nie sú krásne, pretože sa nám páčia (pretože v nás vyvolávajú subjektívne príjemné pocity), ale naopak, páčia sa nám, pretože sú krásne (predpokladáme, že objektívne vyvolávajú pocit všeobecného páčenia sa u všetkých racionálnych bytostí, pričom tento pocit je nezávislý od akéhokol'vek záujmu na ich reálnej existencii - Kant 1975, 58).

Edmund Husserl prehíbil tento spôsob uvažovania a ukázal, že estetické súdenie je založené práve na reflexii somatických stavov vyvolaných percepciou a ich hodnotení. V Logických skúmaniach a v rukopise Wertschätzung und Wert ${ }^{8}$ konštatuje, že každá estetická skúsenost' $\mathrm{v}$ sebe principiálne nesie prvky hodnotenia a oceňovania

\footnotetext{
${ }^{6}$ Gärdenforsov model skúma konceptuálne priestory na základe logicko-sémantickej analýzy pojmov, zatial' čo Hosoyov výskum odhal'uje korelácie konotátov estetických pojmov vzhl'adom na ich empirické použivanie v prirodzenom jazyku.

${ }^{7}$ Estetické emócie sú odlišné napríklad od etických emócií, ktoré obsahujú etické hodnotenia

${ }^{8}$ Odkaz podl'a Byrne (2017). Ide o Husserlov dosial' nepublikovaný rukopis z roku 1909, ktorý možno nájst' vo vychádzajúcej edícii Husserliany - štúdií o štruktúre vedomia.
} 
(Husserl 2009, 403). Podobne uvažuje aj John Drummond. Ten upozorňuje (Drummond 2009) na fakt, že estetické nazeranie možno chápat' ako akúsi somatickú, a teda afektívnu reakciu na pôvodne neafektívne vnímanie. Drummond to ilustruje na príklade strachu zo psa. Ak vidíme psa a máme z neho strach, je to možné len preto, že náš zrak identifikoval objekt ako psa, ktorý je spôsobilý nejako nám ublížit'. Túto skutočnost' následne telesne vnímame ako prežívanie strachu, a tak vieme, že to, čo vidíme, je strašné. Podobne je to aj s krásou. Estetický súd a jeho telesné prejavy sú istou afektívnou a somatickou reakciou na podnety, ktoré vnímame. A to, čo vnímame, nie sú len podnety ako také (objekty), ale aj pocity, ktoré v nás vyvolávajú. Ak teda niečo označujeme za krásne, nevypovedáme tým len o nazeraní čistého fenomenálneho obsahu vedomia, ale zároveň tým vyjadrujeme aj reflexiu svojho vlastného postoja $\mathrm{k}$ tomuto podnetu - hodnotíme ho. Ak vravíme, že niečo je krásne, je to preto, že to v nás vyvoláva pocity, ktoré sa nám páčia. Skratkovito tak v jazyku stotožňujeme objekt nazerania s pocitmi, ktoré v nás vyvoláva (krásna vec vyvoláva krásne pocity; pes je „strašný“, pretože naháňa strach; a škaredé objekty sú škaredé práve preto, lebo vyvolávajú pocity nepríjemna a averzie). Tým krásu vo svete objektivizujeme. Očakávame totiž, že ak označíme niečo za krásne, aj ostatní pozorovatelia budú pocit'ovat' tie isté príjemné pocity, a preto si daný estetický súd bude môct' nárokovat' na všeobecnú platnost' a záväznost'.

Uvedomenie, že estetický súd je hodnotením objektu, ale aj vlastných pocitov a postojov, nie je novým poznatkom. Rovnako nie je nové ani upozornenie na hermeneutické a kognitívne aspekty estetickej skúsenosti. Na Hosoyovom výskume je však novátorské jeho objavenie a empirické potvrdenie skutočnosti, že esteticky sa ako najvýznamnejšie javia práve také emócie, ktoré nie sú celkom čisté a jednostranne orientované, ale skôr tie, ktoré vnímame ambivalentne či komplexne. Predmety, ktoré vyvolávajú hned' celú plejádu rozmanitých pocitov, sú spôsobilejšie esteticky sa nás dotknút' skôr a významnejšie ako tie jednodimenzionálne, pretože využívajú hned' viacero možných „styčných plôch“ prípadného pôsobenia. Ak pritom vyvolávajú aj ambivalentné pocity, nútia nás nad nimi bližšie uvažovat' a vyhodnocovat' ich, vd’aka čomu nám v mysli utkvejú významnejšie a na dlhšie.

Nesporným prínosom Hosoyovho výskumu bolo empirické mapovanie a zhromaždenie súboru najčastejších emócií spätých s vnímaním krásy a estetickou skúsenostou. Pod pojmom estetická skúsenost' mal na mysli široký diapazón emocionálnych stavov, ktorých súčast'ou je estetické hodnotenie. Krása v ňom tvorí len istú oblast' tejto skúsenosti. Estetické emócie zahŕňajú široké a jemne štruktúrované spektrum najrozmanitejších pocitov a rozpoložení, od príjemných stavov („páči sa mi to“, „je to príjemné“, ,prit’ahuje ma to“, „nadchýňa ma to“, „som očarený“", „robí ma to št’astným“, „teší ma to“, až po „rozveselilo ma to“), až po nepríjemné („,nepáči sa mi 
to“, ,je mi to nepríjemné“" ,,vyrušilo ma to“, ,je to škaredé“, ,je to nechutné"). Obsahujú však aj celú skupinu indiferentných a neutrálnych stavov (napr. ,je mi to jedno“), ktoré by sme na pomyselnej osi príjemného a nepríjemného mohli lokalizovat' niekde uprostred. Predkladaný výskum analyzoval 75 základných stavov a emócií, ktoré sa spájajú s estetickou skúsenostou, a ukázal aj niektoré vzájomné vzt'ahy a súvislosti medzi nimi. Na základe toho Hosoya a jeho kolegovia identifikovali 18 aposteriórnych kategórií (nuda, agresia, smútok, strach, zmätenost', radost', krása, uvol'nenie, hrôza, dokonalost', nostalgia, očarenie, prekvapenie, pohnutie, fascinácia, motivácia, záujem, vhl'ad), ktoré združujú uvedené pôvodné vymedzenia, a to s rôznym stupňom vnútornej konzistencie a stability. To im umožnilo vytvorit' dvojdimenzionálnu mapu základných estetických emócií tak, ako ich vnímajú študenti umenovedných odborov.

Spomínaný výskum zmapoval rozloženie základných estetických emócií a ich vzájomných vzt'ahov a empiricky potvrdil mnohodimenzionálnost' estetického emocionálneho priestoru. Je preto na škodu, že autori zostali len pri dvojdimenzionálnom chápaní a znázornení daných emócií a že sa nepokúsili o viacdimenzionálne ponímanie ich modelu či plastickejšie znázornenie jednotlivých vzt’ahov medzi konkrétnymi pocitmi a emóciami. Tým by sa mohli priblížit' ku Gärdenforsovmu modelu, ktorý predpokladá napríklad pri farbe trojdimenzionálny sémantický priestor, čo ponúka aj Osgoodov sémantický diferenciál. Osgood (1964) totiž navrhol metodologický nástroj na meranie rozdielov v individuálnom, psychologickom vnímaní významu pojmov. Uvedomil si, že každý pojem má okrem objektívneho, spoločného a kultúrneho významu, ktorý je definovaný v jazyku, aj subjektívne konotatívne významy. A tie sú charakteristické aj (či najmä) pre vnútorné multidimenzionálne objekty, ako sú estetické emócie. Prostredníctvom použitia troch základných dimenzií osgoodovského sémantického diferenciálu (hodnotenie, sila, aktivita) by tak bolo možné ukotvit' jednotlivé obsahy a poskytnút' základný sémantický referenčný rámec pre mapovanie toho, čo všetko (a v akej sile) máme na mysli napríklad pod pojmom krása. Keby sa ukázalo, že výsledok takto určeného sémantického diferenciálu je nulový, znamenalo by to, že všetci si pod daným pojmom predstavujeme presne to isté. Pojem krásy by preto bol univerzálny a celkom dobre by sa dal definovat'. A naopak, keby bol výsledný rozptyl chápania sémantických priestorov daného pojmu v diferenciáli extrémne vel'ký, znamenalo by to, že daný pojem je vágny, respektíve že každý si pod ním predstavuje niečo iné a pojem neplní svoju komunikačnú funkciu. Komunikovat' totiž môže len to, kde je sémantický prienik dostatočne vel'ký, aby nedochádzalo k neželaným nedorozumeniam.

Vzhl'adom na to, že sekundárne aposteriórne estetické pojmy vznikli združovaním z pôvodne empiricky sýtených primárnych pojmov, Hosoya odhalil relatívne vysokú konzistenciu týchto aposteriórnych pojmoch (od $0,95-0,59$ ), avšak s najmenšou nameranou hodnotou práve pri kategórii „krásy“( 0,51$)$. Znamená to, že práve „krása“ 
ako klúčový pojem sa vyznačuje najmenšou vnútornou súdržnost'ou a pri jeho chápaní sa možno stretnút' s najväčšími odchýlkami. „Páčenie sa“ je najčastejšie spájané s „krásou“, „potešením“, „príjemnost’ou“ a „radost’ou“. Opačne - „nepáčenie sa“ je zasa späté so „škaredost'ou“, „nechut’ou“, „nepríjemnost'ou“, „rušením“. Vnímanie krásy teda možno znázornit' ako isté kontinuum s rôznymi stupňami pocit'ovania príjemných pocitov (od príjemna cez páčenie sa, krásu až po rozkoš či extatické stavy). $\mathrm{Na}$ druhej strane tej istej dimenzie je vnímanie negatívnych pocitov a emócií, ako sú odpor, zhnusenie, škaredost' a nepáčenie sa. Niekde medzi týmito stavmi možno nájst' indiferentné a neutrálne pocity, ktorých intenzita či obsahy môžu byt' taktiež rozmanité (od l'ahostajnosti až po reflektované, no bezpríznakové - neutrálne stavy). Rôzny stupeň saturácie dimenzie príjemnosti (miera intenzity zážitku) nám tak umožňujú vyjadrit' mieru krásy a vysvetlit' možnost' existencie gramatického stupňovania (pekný, krajší, najkrajší).

Druhou charakteristickou črtou estetických emócií sú pocity, ktoré vyjadrujú istú aktivitu alebo zmenu stavu vzhl'adom na množstvo pocit’ovanej energie alebo motivácie konat'. Hosoya zistil, že najčastejšími kolokáciami vnímania krásy sú pocity „,vzrušenia“, „radosti“, „prit’ahovania“, „túžby“, ,,energizovania“, ,motivovania“, ale aj „pohnutia“, „dotknutia“. Rovnako však existujú aj estetické emócie smerujúce k ,uvol’neniu“, „,upokojeniu“, „harmónii“ a k „,melancholickým“ pocitom, k „,nostalgii“, „,sentimentu“, „smútku“, a k „,depresii“. To, čo spája tieto emócie, je tlmenie aktivity, ustatie alebo absencia motívu či energie niečo robit'. Tak je to aj pri „nude“ a „únave“. Negatívne estetické emócie sú, naopak, často spájané s aktivitou (najčastejšie s hnevom „hnevá ma to“) a agresivitou. To koreluje so Zekiho zisteniami (Ishizu, Zeki 2011), že neuronálne koreláty ,škaredosti“ sa spájajú najmä so senzomotorickým kortexom a snahou o odvrátenie pohl'adu či pozornosti, zatial' čo krása s centrom odmien a kontempláciou. Pri estetických emóciách vyvolávajúcich ,agresiu“, „hnev“, „strach“ či „hrôzu“, ale aj pri pozitívne prežívaných emóciách, ako sú „,radost”“, „prekvapenie“ a „fascinácia“, pocit'ujeme nárast energie a tomu zodpovedajúcej aktivity vyvolanej estetickým nazeraním. Vzrušenie - aktivita a pasivita - je (po príjemnosti a nepríjemnosti) druhou zo základných dimenzií estetickej skúsenosti a vyjadruje mieru motivácie konat', ale aj prípadné smerovanie konania.

Existencia dvoch základných dimenzií estetických emócií nám umožňuje v priestore lokalizovat' dva rozličné emocionálne stavy podl'a ich odlišných súradníc. Paul Churchland $(1989,106)$ navrhoval model , ktorým by sa dala vyjadrit' kvalita nejakého subjektívneho vnemu (napr. vnímania červenej farby) prostredníctvom merania aktivít $\mathrm{v}$ troch dimenziách, vytváraných navzájom odlišnými čapíkmi. „To, čo niekto vidí ako ,nevýslovne ' ružové, je možné obsažne a presne vyjadrit' ako ,akord ‘ s frekvenciou $95 \mathrm{~Hz} / 80 / \mathrm{Hz} / 80 \mathrm{~Hz}$ v príslušnom trojjedinom kortikálnom systéme“ 
(citované podl'a Flanagan 1995, 37 - 38). Podobne by potom malo byt' možné vyjadrit' aj obsahové osobitosti každého estetického emočného stavu. Ak sa napríklad dívam na atraktívnu ženskú postavu alebo na tvár diet’ata, prípadne krajinnú scenériu, je možné, že uvedené objekty vo mne vyvolávajú rovnakú mieru potešenia ako napr. šálka dobrej kávy. Je pochopitel'né, že napriek identickej intenzite príjemnosti pocitov ich obsahy vo mne vyvolávajú celkom odlišné emocionálne pocity. Na ich odlíšenie treba sledovat' mieru saturácie aj iných dimenzií, ako je len príjemnost'. Keby sa nám podarilo postihnút' všetky dimenzie všetkých estetických skúseností, mohli by sme navzájom odlíšit' aj všetky emočné stavy, ktoré sú danými dimenziami charakterizované. Jednotlivé emócie by sa totiž navzájom odlišovali práve mierou saturácie aspoň jednej z uvedených dimenzií.

Dve rovnako príjemné skúsenosti tak môžu odlišne skórovat' v inej dimenzii napríklad vyjadrujúcej mieru aktivity, ktorú v nás daný objekt vyvoláva. Atraktivita (napr. ženy) zväčša vyvoláva túžbu, vášeň, chcenie. To je podstata prít'ažlivosti. Vyvoláva pohyb. Krajinná scenéria, napríklad, môže prinášat' rovnaký pôžitok čo do svojej intenzity, jeho obsahom však nebude vášeň, túžba či vzrušenie, ale naopak - pokoj, uvol'nenie a stíšenie. Pri niektorých krásnych objektoch môžeme zasa vzhl'adom na ich krehkost', duchovnú či inú hodnotu pocit’ovat' bázeň, rešpekt či iné emócie, ktoré nám zabraňujú približovat' sa $\mathrm{k}$ nim či usilovat' sa o ne. To však nič nemení na kráse, ktorú vyžarujú.

Dimenzie príjemnosti a nepríjemnosti či aktivity a pasivity predstavujú len istú oblast' estetických skúseností. Tie sú v skutočnosti podstatne rozmanitejšie a komplexnejšie. Ďalšími rovinami predkladaného výskumu boli poznávanie a záujem. Výskumníci si všimli, že medzi estetickými emóciami existujú také, ktoré sú charakteristické nárastom aktivity aj pozitívnym hodnotením, ktoré však nebolo priamo spojené s vnímaním senzorického pôžitku či príjemných pocitov. Takýmito estetickými emóciami sú najmä „fascinácia“, „očarenie“, ,prekvapenie“ či „,pôvab a dokonalost““, ale aj „,intelektuálna stimulácia“ a „vhl’ad“. Opačne pôsobili „zmätenost““ a „nezáujem“.

Pozoruhodným záverom uvedeného empirického výskumu bolo zistenie, že „krása“ a „škaredost"“ nezaujímajú centrálne a celkom opozitné postavenia v sémantickom priestore skúmaných subjektov.

V niektorých teóriách umenia sa možno stretnút's názorom, že to, o čo v umení ide, je práve krása a príjemný zážitok. Existujú však aj filozofi (napr. McMahon 2001), ktorí veria, že umenie aj bez krásy a krása môžu existovat’ aj bez príjemných pocitov. Estetickú hodnotu umeleckého objektu môžem pocit'ovat' aj bez príjemného pocitu $\mathrm{v}$ zmysloch, napríklad na základe vnímania iných (napr. intelektuálnych) 
hodnôt. Duchampova Fontána, či Picassove Les Demoiselles d'Avignon ${ }^{9}$ majú svoju estetickú hodnotu, ktorá tkvie napr. v ich novátorstve, videní sveta, v technike zobrazenia či v kvalite prevedenia. Nemusia sa nám páčit' v zmysle senzorického pôžitku, ale uvedomujeme si ich estetickú hodnotu. Estetická hodnota totiž predstavuje celkovú estetickú kvalitu daného predmetu, ktorá vzniká v procese recepcie daného objektu, ${ }^{10}$ a integruje v sebe hned' niekol'ko odlišných kvalít a dimenzií.

Hosoyov výskum potvrdil význam dokonalosti ako samostatného obsahu estetických emócií. Hodnotíme veci vzhl'adom na ich jednoduchost', ${ }^{11}$ výnimočnost', originalitu či kvalitu spracovania. Uvedené kvality predstavujú akúsi intelektuálnu dimenziu estetickej skúsenosti, pri ktorej je potrebné isté intelektuálne spracovanie a hodnotenie. Hosoya definuje „prekvapenie“ a „fascináciu“ ako samostatné kategórie, ku ktorým prirad’uje aj ,intelektuálny záujem“ a „vhl'ad“. Všetky uvedené kategórie predpokladajú isté porozumenie problému. Posúdenie novosti a výnimočnosti diela predpokladá schopnost' komparácie s dosial' pozorovanými objektmi. Moment neznámeho v nich zasa zvyšuje atraktivitu a záujem o daný objekt. Aby sme ale mohli komparovat', musíme vopred disponovat' celou množinou predchádzajúcich skúseností (Démuth 2016) a zároveň musíme to „nové riešenie“ zbadat' a spoznat' ho ako „nové“. Záujem o novost' nie je len prejavom pozornosti, ale aj schopnosti spoznat' nezvyčajné ako nezvyčajné a ocenit’ ho. Preto sú pre Hosoyu také dôležité fascinácia a prekvapenie, ktoré sú dôkazom mentálnej stimulácie a vhl’adu. Podla S. Markoviča (2012) je estetická fascinácia dokonca jedným z troch základných komponentov estetickej skúsenosti. Estetický záujem vyjadruje nielen schopnost' vecí upútat' našu pozornost', ale aj spracovanie senzorických vstupov ako intelektuálny problém.

\section{Záver - návrh spoločného modelu}

Každá z dvoch predložených štúdií pristupuje ku skúmaniu estetických pojmov odlišným spôsobom, pritom však oba spôsoby možno vel'mi dobre kombinovat'. Gärdenforsova teória konceptuálnych sémantických priestorov umožňuje vnímat' estetické pojmy $\mathrm{v}$ geometrickom poli s možnostou relatívne presného vymedzenia

\footnotetext{
${ }^{9}$ Mimochodom, práve uvedené dve diela boli v roku 2004 vyhodnotené 500 expertami za najvýznamnejšie umelecké diela vôbec. Porov. Duchamp's urinal tops art survey. Story from BBC NEWS: http://news.bbc.co.uk/go/pr/fr/-/2/hi/entertainment/4059997.stm; Publikované: 2004/12/01 17:56:19 GMT.

${ }^{10}$ Proces recepcie estetického objektu a jeho reflexia pritom predstavuje estetickú skúsenost'.

${ }^{11}$ Ako ukazujú Winfried Menninghaus a kol. (2019a), pojem „elegancia“, vyjadrujúci jednoduchost’ v dokonalom stvárnení krásy, je významovo i terminologicky nový a bol prebraný takmer do všetkých jazykov v pôvodnej latinskej podobe. Zistenie je súčast’ou širšieho, dosial' prebiehajúceho výskumu Elegance, realizovaného na Max-Planck-Institut für empirische Ästhetik. Porov. https://www.aesthetics.mpg.de/en/research/department-of-language-and-literature/fundamentalconcepts-of-aesthetics/projekte/elegance.html.
} 
jednotlivých konvexných regiónov, ktoré označujú. Dôležitou súčast'ou jeho modelu je správne určenie kl'účových dimenzií, ktoré tvoria kostru celého sémantického priestoru. To je možné urobit’ intuitívne, konceptuálnou analýzou, ale aj empiricky.

Hosoyov výskum napíňa gärdenforsovský model empirickým obsahom. Ukazuje, že v bežnom jazyku existujú klúčové estetické pojmy a skúma ich vzájomné vzt'ahy u užívatel'ov daného jazyka. Prostredníctvom zhlukovej analýzy tak umožňuje testovat' správnost' intuitívne zvolených estetických dimenzií, prípadne ich upresňuje a dopína. Kombináciou oboch prístupov by tak malo byt' možné vytvorit' jednotný model sémantických priestorov estetických pojmov a estetických emócií a poskytnút' nástroj na relatívne presné opísanie jeho vnútorných štruktúr a vzt'ahov jednotlivých pojmov.

Mnohé estetické emócie sú natol'ko členité, že máme problém pomenovat' a rozlíšit' ich. Niektoré môžu byt' napríklad rovnako príjemné či nepríjemné, ale odlišujú sa niektorými inými charakteristikami. Tie sa prejavujú odlišnou mierou sýtenia iných dimenzií, a práve to by nám malo napomôct' rozlíšit' ich. ${ }^{12}$ Pri niektorých zasa možno nájst' úplne odlišné obsahové orientácie, hoci v iných oblastiach budú pôsobit' vel'mi podobne. Predkladaný model predpokladá multidimenzionálnu štruktúru estetickej skúsenosti, a teda aj to, že jednotlivé skúsenosti sa budú od seba líšit' práve jedinečnými koordinátmi na niektorej z posudzovaných dimenziî. ${ }^{13}$ Ich zmapovaním a meraním saturácie jednotlivých dimenzií v multidimenzionálnom priestore by tak malo byt' možné opísat' nielen pozíciu každej emócie vo vzt’ahu k iným emóciám, ale aj (v rámci tej istej konvexnej oblasti charakterizujúcej danú skupinu emócií) rozlíšit jemné významové odlišnosti tej istej skupiny pocitov. To však predpokladá d’alší podrobný výskum, ku ktorému chce byt' predkladaná štúdia pozvaním, ale aj výzvou na vytvorenie podrobnejšieho modelu geometrizovania a mapovania sémantických priestorov estetických pojmov.

\footnotetext{
12 Predstavovaný model pojmu estetická skúsenost' predpokladá rôzne stupne intenzity avšak typovo rovnaký druh (napr.) príjemnosti pri odlišných estetických pocitoch. Predpoklad sa opiera o poznatky z neurovedeckých výskumov identifikujúcich ten istý neurofyziologický a psychologický základ potešenia pre rôzne emocionálne stavy a odmieta diametrálne odlišné druhy estetických slastí. (O neurofyziológii pôžitku a úlohu primárneho okruhu odmien pre vznik príjemných pocitov pozri napr. Démuth 2019a; Linden 2011). Obsahová odlišnost' jednotlivých estetických pocitov je potom daná odlišnou mierou saturácie všetkých jednotlivých dimenzií konštitujúcich daný pocit a ich odlišnou kombináciou.

${ }^{13}$ Nejde teda o rozdiely v počte jednotlivých konotovaných pojmov ani o celkový počet všetkých konotácií pojmov, ale o rozličnú mieru (intenzitu), ktorou sú sýtené jednotlivé sémantické dimenzie charakterizujúce daný pojem.
} 


\section{Literatúra}

BYRNE, T., (2017): The Feeling of Beauty: The Role of the Body in Aesthetic Experience. In: Phenomenology and Aesthetics. The 3rd Conference on Traditions and Perspectives of the Phenomenological Movement in Central and Eastern Europe. 29 June - 1 July, 2017.

ECO, U. (ed.) (2005): Dějiny krásy. Praha: Argo.

DÉMUTH, A. (2016): Tri historické matematické prístupy ku skúmaniu krásy. Filozofia, 71 (9), $759-770$

DÉMUTH, A. (2017): Conceptual Analysis of the Concept of Beauty in Cognitive-Scientific Research. In: Démuth, A. (ed.): The Cognitive Aspects of Aesthetic Experience - Introduction. Frankfurt am Main: Peter Lang, 31 - 52.

DÉMUTH, A. (2019a): Beauty, Aesthetic Experience, and Emotional Affective States. Berlin: Peter Lang Verlag.

DÉMUTH, A. (2019b): Fenomenologicko-existenciálna analýza krásy. Filosofický časopis, 67 (4), $561-575$.

DÉMUTHOVÁ, S. (2019): Krása v kontexte evolučných prístupov. Filosofický časopis, 67 (4), 591 $-604$.

DRUMMOND, J. (2009): Feelings, emotions, and truly perceiving the valuable. The Modern Schoolman, 86: 363 - 379. DOI: 10.5840/schoolman2009863/49

DUCHAMP'S URINAL TOPS ART SURVEY. BBC NEWS. Dostupné na: http://news.bbc.co.uk/ go/pr/fr/-/2/hi/entertainment/4059997.stm; Publikované: 2004/12/01 17:56:19 GMT.

FLANAGAN, O. (1995): Vedomie. Bratislava: Archa.

GÄRDENFORS, P. (2000): Conceptual spaces: the geometry of thought. Cambridge, Mass.: MIT Press.

GÄRDENFORS, P. (2014): Geometry of meaning: semantics based on conceptual spaces. Cambridge - Mass.: MIT Press.

GÄRDENFORS, P. (2015): Geometrizovanie myslenia. Pusté Úl'any: Schola Philosophica.

GÄRDENFORS, P., DÉMUTH, A. (2013): Geometrizovanie významu. Rozhovor s Petrom Gärdenforsom. Filozofia, 68 (7), $621-624$.

HOSOYA, G., SCHINDLER, I., BEERMANN, U., WAGNER, V., MENNINGHAUS, W., EID, M., SCHERER, K. R. (2017): Mapping the Conceptual Domain of Aesthetic Emotion Terms: A Pile-Sort Study. Psychology of Aesthetics, Creativity, and the Arts, 11 (4), 457 - 473. DOI: https://psycnet.apa.org/doi/10.1037/aca0000123

HUSSERL, E. (2009): Logische Untersuchungen. Hamburg: Felix Meiner Verlag.

CHURCHLAND, P. M. (1989): A Neurocomputational Perspective: The Nature of Mind and Structure of Science. Cambridge: MIT Press.

ISHIZU, T., ZEKI, S. (2011, July, 6): Toward A Brain-Based Theory of Beauty. PLOS ONE. DOI: https://doi.org/10.1371/journal.pone.0021852

KANT, I. (1975): Kritika soudnosti. Praha: Odeon.

LEVINSON, J. (2014): Beauty is Not One: The Irreducible Variety of Visual Beauty. In: Schellekens, E, Goldie P. (eds.): The Aesthetic Mind. Oxford: Oxford University Press, 190 - 207.

LINDEN, D. (2011): The Compass of Pleasure. New York: Penguin Books.

MARKOVIČ, S. (2012): Components of aesthetic experience: aesthetic fascination, aesthetic appraisal, and aesthetic emotion. i-Perception 3 (1), 1 - 17. DOI: https://doi.org/10.1068/i0450aap.

MCMAHON, J. (2001): Beauty. In: Gaut, B. and Lopes, D. (eds), The Routledge Companion to Aesthetics. London: Routledge, $227-238$.

MENNINGHAUS, W., WAGNER, V., HANICH, J., WASSILIWIZKY, E., JACOBSEN, T., KOELSCH, S.,(2017): Authors 'Response: Negative emotions in art reception: Refining Theoretical Assumptions and Adding Variables to the Distancing-Embracing Model. Behavioral and Brain Sciences, 40, 44 - 51. DOI: https://doi.org/10.1017/S0140525X17001947. 
MENNINGHAUS, W., WAGNER, V., KEGEL, V., KNOOP, C. A., SCHLOTZ, W. (2019a): Beauty, elegance, grace, and sexiness compared. PLoS ONE 14 (6): e0218728. DOI: https://doi.org/10.1371/journal.pone.0218728

MENNINGHAUS, W., WAGNER, V., WASSILIWIZKY, E., SCHINDLER, I., HANICH, J. JACOBSEN, T., \& KOELSCH, S. (2019b): What Are Aesthetic Emotions? Psychological Review 126 (2), 171 - 195. DOI: https://doi.org/10.1037/rev0000135.

OSGOOD, C. E. (1964): Semantic differential technique in the comparative study of cultures. American Anthropologist 66 (3), 171 - 200.

ZENKER, F., GÄRDENFORS, P., (eds.) (2015): Applications of conceptual spaces: the case for geometric knowledge representation. Synthese library: studies in epistemology, logic, methodology, and philosophy of science. Cham: Springer-Verlag.

\author{
Andrej Démuth \\ Právnická fakulta \\ Univerzita Komenského v Bratislave \\ Šafárikovo námestie 6 \\ 81000 Bratislava \\ Slovenská republika \\ e-mail: andrej.demuth@uniba.sk \\ ORCID ID: https://orcid.org/0000-0003-3133-2908
}

